\title{
New Chemistry Department, University of Edinburgh.
}

' $\mathrm{HE}$ Chemical Laboratories, the foundation stone of which was laid by the King on July 6 , I920, were formally opened by the Prince of Wales on December 3. The University had resolved in I9I3 to build a new chemistry department, and detailed plans were drawn up for its construction, but the outbreak of war led to the postponement of the scheme. Early in I9I9 the matter became of immediate urgency, as it had by that time become evident that large numbers of ex-service men were about to enter on university courses in pure and applied science, as well as in medicine. The University met the situation by resolving first to appoint a professor of chemistry in relation to medicine, who would be accommodated in the old laboratories, and second, this basement is a separate entrance for elementary students. The consiruction is mainly of brick relieved by stonework on the frontage, which faces due north. The whole building is fireproof, floors and roofs being of reinforced hollow tile.

The general lay-out is indicated by Fig. 2. Three parallel corridors running north and south meet at one end the east and west corridor of the front block, and at the other end are free for extension. Between the central and side corridors are the main laboratories and lecture rooms with their subsidiary offices and service rooms. These are all lit on the factory shed principle by a saw-tooth roof, glazed with north slope window-lights. On the outer face of each side corridor is a range of rooms lit by large windows in

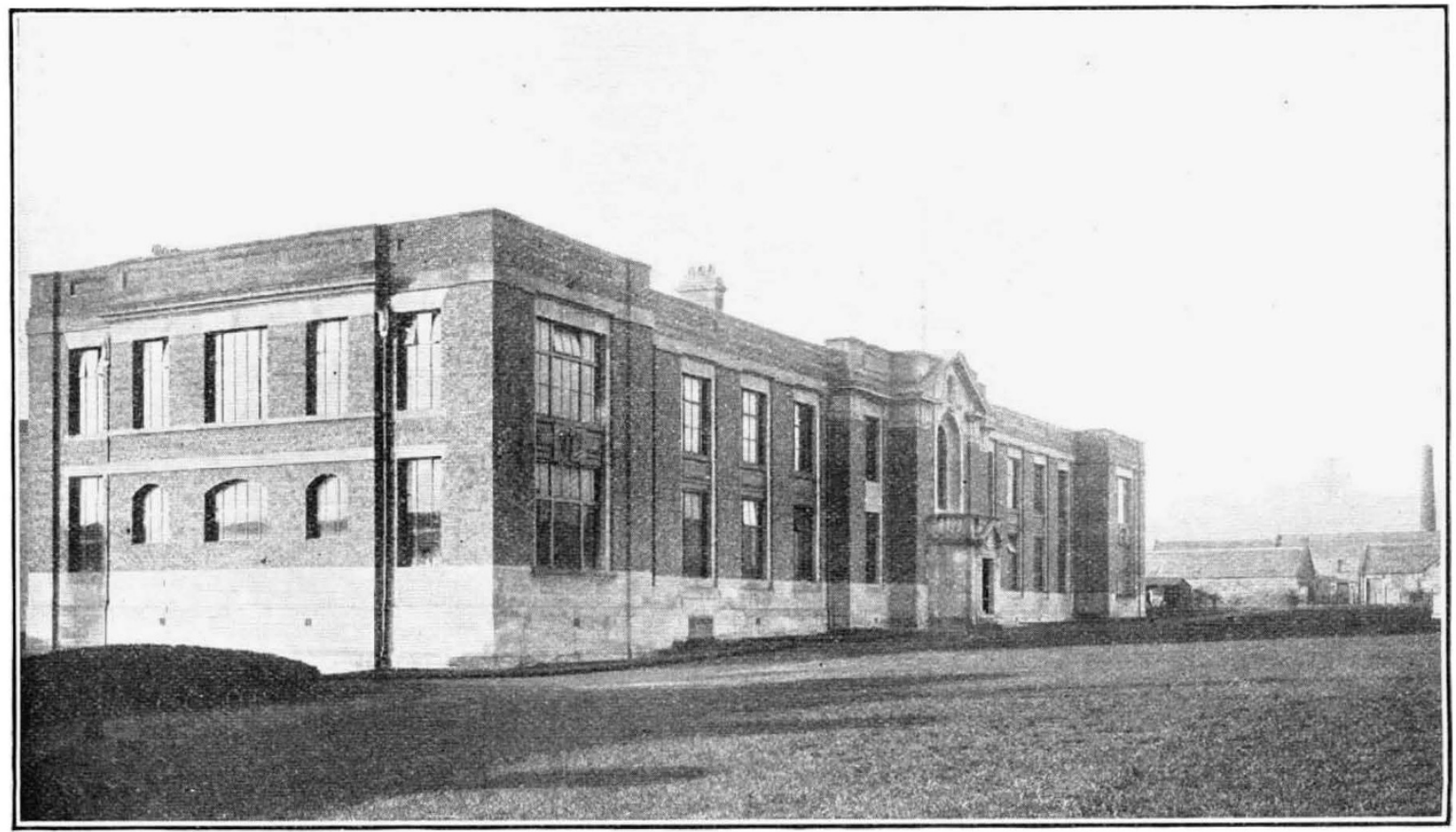

FIG. 1.-The King's Buildings, University of Edinburgh (Chemistry Dəpartment).

to erect a new chemistry department on a site affording greater facilities for adaptation and extension than the site originally contemplated.

The University accordingly purchased some farm land on the southern outskirts of the city, about a mile and a half from the Old College. This land, of I I 5 acres in extent, is intended to provide sites for all the scientific departments of the University, which will, as necessity determines and as money becomes available, move out to the King's Buildings, the new group being so named with His Majesty's permission.

The Chemistry Building (Fig. I), excavation for which was begun in November rgrg, has a frontage of 220 feet and a depth of 320 feet. It was constructed by Mr. A. F. Balfour Paul, architect, on sketch plans submitted by the professor of chemistry, Sir James Walker. The front block is of two storeys; the remainder is of one storey only, with the exception of a small section to the south-east which has a basement for an engineer's house, cloak-rooms, etc. In

$$
\text { NO. } 2876 \text {, VOL. I I } 4]
$$

the walls. These serve as balance-rooms, etc., for the main laboratories, and as research rooms. On the ground floor of the front block are the physicochemical laboratories, dark-rooms, and special rooms for gas-analysis, etc.; on the upper floor are the library, administrative rooms, staff common-room, research rooms, and laboratories destined for crystallography, X-ray work, and the like.

The main laboratories are four in number, each $45 \times 70$ feet internal measurement. They are fitted with benches to accommodate $72 \times 4=288$ students in the elementary laboratory, $72 \times 2=144$ students in the laboratory of the second year, 48 students in the advanced inorganic laboratory, and 40 students in the advanced organic laboratory. The physicochemical rooms can provide working places for about 30 students. Thus the department could take more than 260 students working simultaneously, and has a bench. capacity for $55^{\circ}$ students. In the special research rooms at present equipped, accommodation can be found for 25 post-graduate workers, a number 
capable of being doubled when all the rooms are completed.

A section of the department is devoted to technical chemistry, the object being to familiarise students in a general way with technical plant and processes. There are three small general working laboratories, two research rooms, and a workshop, with office, stores, etc. The equipment is for the most part of a mobile type, the main rooms being fitted on the walls with service pipes for water, gas, steam, electric light and power, compressed air and vacuum, to which smallscale plant can be connected. From I 5 to 20 students can simultaneously receive instruction in this section.

There are four lecture rooms, two large (seating capacity I60) and two small (seating capacity 100 and 70 respectively). These are lit by cupolas and three of them can be darkened by lowering a false ceiling operated electrically. The four lecture rooms are served by a single preparation room, adjoining which is a commodious lecture museum.

The heating of the department is effected by means of low-pressure steam, and the ventilation is by extraction, the main inlet duct being under the central corridor, and all air being admitted to rooms over steam pipes or radiators. Each main laboratory is served by an independent fan connected with draught-holes on the students' benches, a scavenging fan being also provided at a high level. The draught-cupboards of the department are connected with two special high-power fans. Each pair of lecture rooms has a fan which runs normally at a low speed, but is capable of changing the air of the room completely in a few

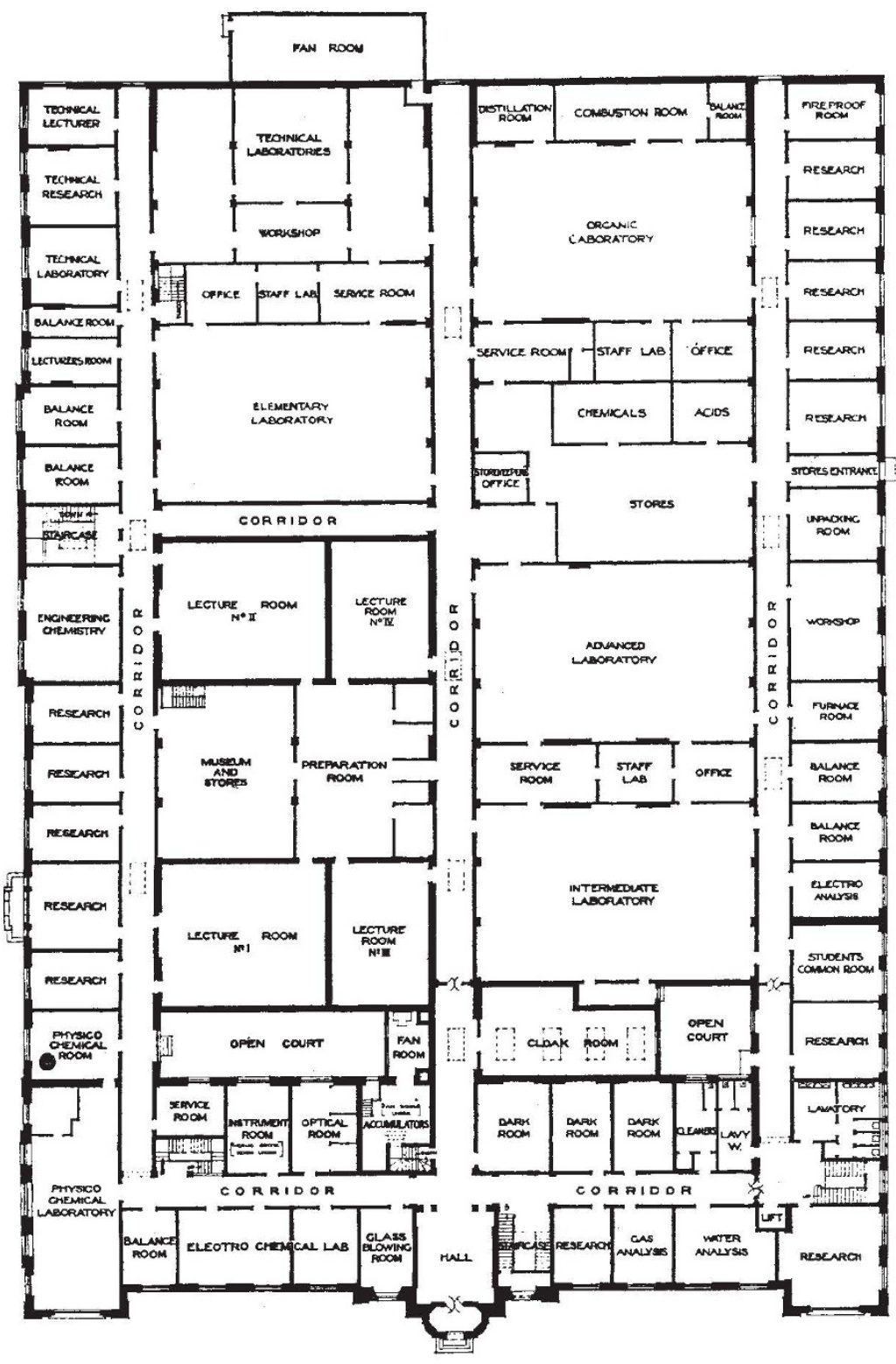

PLAN OF GROUND FLOOR

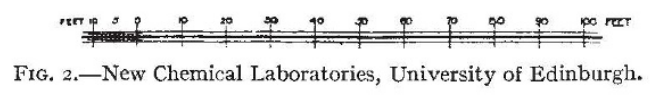

minutes between lectures. The air is admitted under the lecture bench and extracted through two sets of apertures in the back wall of the lecture room, one set at head level and the other near the roof.

Electricity is supplied from the city at 230 volts A.C. and 460 volts D.C. for power. A large motor gen erator yields direct current at Ioo volts for wall plugs, and for charging accumulators, of which there are two sets of 20 cells each-one for electroanalytic and electro-syn. thetic work, the other for physico-chemical work.

The first section of the department was fully occupied in October I92I, the second in October I922, and the third and final section in October I924. The actual cost of the buildings, inclusive of scientific equipment and a 11 other charges, has been somewhat les $\mathrm{s}$ than $200,000 l$.

At a luncheon following the admission of the Prince to the honorary LL.D. degree, the Principal announced that the deficit of $88,000 l$. on capital incurred since the War had in the preceding few days been met to the extent of $75,000 l$. by subscriptions, including a donation of $50,000 \mathrm{l}$. from Sir Alexander Grant. 